\title{
Pemberdayaan Ibu-Ibu PKK Desa Suka Ramai, Kec. Tapung Hulu, Kab. Kampar dengan Produk Facemist Berbahan Dasar Aloevera Dan Ekstrak Green Tea
}

\author{
Rahmiwati Hilma*, Prasetya, Jufrizal Syahri, Hasmalina Nasution, Rahmadini Syafri, \\ Sri Hilma Siregar, Fitra Perdana
}

Fakultas MIPA dan Kesehatan

Universitas Muhammadiyah Riau

email: rahmiwatihilma@umri.ac.id

\begin{abstract}
The Covid-19 pandemic has had a significant impact on the social and economic life of the global community, including the people in Suka Ramai Village, Kec. Tapung, Kab, Kampar. The high price of medicines, including cosmetics, the economic crisis that has not yet gradually recovered has caused depression for the community, especially for mothers. In this activity, empowerment was carried out in the form of counseling and training for PKK mothers, posyandu cadres and young women to produce their own multipurpose facemist products for health and beauty. In the health sector, this product is antidepressant and beauty provides freshness, acts as an antioxidant, antiaging and reduces acne on the face. This activity is carried out offline with strict health protocols. The activity was carried out well, as seen by the enthusiasm of the participants for the training materials, the number of participants did not change from the beginning of the activity to completion. From this activity, the "ESM" facemist product was produced by the trainees. The PKK ladies and Mr. Suka Ramai Village Head, are very grateful for the implementation of the activities in their village and hope that other activities will also be carried out in the village
\end{abstract}

Keywords: Covid-19 pandemic, facemist, aloevera, green tea

\begin{abstract}
Abstrak
Pandemik Covid-19 memberikan dampak yang signifikan terhadap tatanan kehidupan sosial dan ekonomi masyarakat global, termasuk masyarakat di Desa Suka Ramai, Kec. Tapung, Kab, Kampar. Tingginya harga obat-obatan termasuk kosmetik, krisis ekonomi yang belum juga berangsur pulih menimbulkan depresi bagi masyarakat, terutama bagi Ibu-ibu. Pada kegiatan ini dilakukan pemberdayaan berupa penyuluhan dan pelatihan bagi Ibu-ibu PKK, kader posyandu dan remaja putri untuk memproduksi sendiri produk facemist multiguna untuk kesehatan dan kecantikan. Dibidang Kesehatan produk ini bersifat antidepresan dan kecantikan memberikan kesegaran, bersifat sebagai antioksidan, antiaging dan mengurangi jerawat pada wajah. Kegiatan ini dilakukan secara luring dengan protokol kesehatan yang ketat. Kegiatan terlaksana dengan baik, terlihat dengan antusias peserta akan materi-materi pelatihan, jumlah peserta yang tidak berubah dari awal kegiatan sampai selesai. Dari kegiatan ini dihasilkan produk facemist "ESM" yang diproduksi oleh peserta pelatihan. Ibu-ibu PKK dan Bapak Kepala Desa Suka Ramai, sangat berterima ksih atas terlaksananya kegiatan di Desa mereka dan berharap akan ada kegiatan lain yang juga dilaksanakan di Desa tersebut.
\end{abstract}

Kata Kunci: Pandemik Covid-19, facemist, aloevera, green tea

\section{PENDAHULUAN}

Desa Suka Ramai adalah sebuah desa defenitif hasil pemekaran Desa induk yaitu Desa Sinama Nenek pada tahun 2002. Desa Suka Ramai merupakan wilayah yang berada di Kecamatan Tapung Hulu,
Kabupaten Kampar. Luas wilayah Kabupaten Kampar mencapai 10.983,47 $\mathrm{km}^{2}$. Pada tahun 2021, jumlah penduduk Kab. Kampar xmencapai 841.332 jiwa. Kecamatan Tapung Hulu memiliki 14 Desa termasuk Desa Suka Ramai, dengan 
jumah penduduk 80.108 jiwa. Kondisi wilayah kecamatan Tapung Hulu merupakan dataran rendah yang relatif datar meliputi kawasan perkebunan kelapa sawit, perumahan, pertokoan, dan sekolah. Masyarakatnya yang heterogen baik secara sosial dan ekonomi tercemen dari berbagai suku yang tinggal diwilayah Desa Suka Ramai ini dan adanya berbagai macam profesi dan usaha. Sebagian besar kepala rumah tangga di kecamatan Tapung Hulu bekerja pada perkebunan kelapa sawit 97,38\%, Kelapa 0,07\% dan karet 2,54\%. Ibu-ibu nya kebanyakan hanya mengurus rumah tangga dan melakukan kegiatan positif seperti kegiatan PKK, posyandu dan arisan. Dari sisi pendidikan hanya $10,94 \%$ yang menyelesaikan pedidikan perguruan tinggi, sedangkan untuk jenjang sekolah menengah sebanyak $14,95 \%$ dan selebihnya tidak/belum sekolah [1].

Pandemi COVID-19 memberikan dampak yang signifikan terhadap tatanan kehidupan masyarakat Desa Suka Ramai, terutama bidang ekonomi dan sosial. Tingginya harga obat-obatan termasuk kosmetik, krisis ekonomi yang belum juga berangsur pulih menimbulkan depresi bagi masyarakat, terutama bagi Ibu-ibu. Seperti diketahui perempuan dua kali lipat beresiko mengalami depresi dibandingkan laki-laki, hal ini diperkirakan adanya perbedaan hormon, pengaruh melahirkan, dan perbedaan stresor psikososial [2].

Lidah buaya (Aloevera) adalah salah satu tanaman obat tradisional yang termasuk dalam suku Liliaceae, sering ditanam dipot atau halaman rumah. Aloevera sudah dimanfaatkan untuk bahan baku kosmetik sejak zaman Cleopatra. Bangsa Arab telah lama memanfaatkan tanaman yang dijuluki "the miracle plant" tersebut untuk pengobatan dan bahan kosmetik. Bangsa Yunani dan Romawi, telah menggunakan lidah buaya untuk mengatasi berbagai masalah kesehatan, diantaranya sebagai penyubur rambut dan memperhalus kulit [3]. Lidah buaya bersifat antibiotik, antiseptik, antibakteri, antikanker, antivirus, anticendawan, antiinfeksi, antiradang, antiinflamasi, antiaterosklerosis dan antivirus [4].

Herbal medicine yang lain di antaranya adalah teh hijau. Saat ini, masyarakat Asia termasuk Indonesia mempercayai bahwa teh hijau mengandung zat yang berguna untuk pencegahan dan penyembuhan berbagai jenis penyakit antara lain sebagai antikarsinogenik, antioksidatif, antialergi, antihipertensi, antibakterial, antikariesgigi, antimetastatik, imunomodulator, antihiperkolesterolemia [5]. Sifat antialergi pada teh hijau diduga karena mengandung senyawa aktif polifenol, sementara kandungan flavonoid (cathecin) mempunyai aktivitas sebagai immunomoduator [6]. Keduanya juga mempunyai sifat aktivitas antioksidan yang berkontribusi positif bagi kesehatan manusia [7]. Stres oksidatif (kondisi ketidakseimbangan antara jumlah radikal bebas yang ada dengan jumlah antioksidan di dalam tubuh) berperan penting dalam patofisiologi terjadinya proses menua dan berbagai penyakit degeneratif. Antioksidan sangat diperlukan oleh tubuh untuk mengatasi dan mencegah stres oksidatif tersebut [6],[7].

Masyarakat umumnya belum banyak yang mengetahui manfaat daun teh dan aloevera kaya akan senyawa antioksidan dan bisa juga mempunyai efek antidepresan alami. Biasanya aloevera digunakan sebagai masker atau unutk mengobati lika bakar dan green tea sebagai obat jerawat. Melihat dari kasus ini, ekstrak green tea dan aloevera akan dibentuk menjadi spray wajah. Penggunaan spray wajah ini praktis sehingga banyak disukai oleh adam dan kaum hawa, selain praktis spray wajah juga ditambahkan aromaterapi yang akan menenangkan syaraf-syaraf sehingga dapat mengurangi tingkat stress yang dialami [8].

Pada kegiatan ini kami melatih ibuibu PKK dan ibu-ibu yang aktif di 
Posyandu Desa Suka Ramai untuk mencari alternatif lain dalam menjaga kesehatan dengan "kembali ke alam" (back to nature), mengembangkan produk spray wajah multiguna dari ekstrak green tea, aloevera dan air mawar yang mudah didapatkan dan bisa dimanfaatkan untuk menjaga kesehatan kulit wajah tetap fresh, mencegah dan mengobati jerawat, bisa untuk mengobati luka dan memberikan aspek rileksasi (antistress) bagi penggunanya. Tanaman aloevera cukup mudah ditemui dan kelimpahan cukup banyak bahan baku. Cara spray (semprot) ini dipilih karena lebih memudahkan pemakaiannya, produknya diberi nama Euphorbia Spray Multiguna "ESM".

Produk ini menjadi solusi yang ditawarkan dalam membantu Ibu-Ibu PKK dan remaja putri Desa Suka Ramai, Kec. Tapung Hulu, untuk mengatasi masalah yang mereka hadapi dengan mengadakan pemberdayaan berupa memberikan pengetahuan praktis dan rangsangan kepada masyarakat, serta pelatihan pembuatan produk produk kesehatan dan kecantikan dalam bentuk facemist yang sederhana dan praktis berbahan dasar aloevera dan ekstrak green tea. Produk facemist bisa dimanfaatkan untuk kesehatan karena bersifat antidepresan, menjaga kulit wajah.

\section{METODE PENGABDIAN}

Adapun rangkaian alur pelaksanaan Pengabdian Pada Masyarakat ini terdiri dari tiga tahap, yaitu: pra-kegiatan, pelaksanaan kegiatan, evaluasi dan tindak lanjut pelaksanaan program. Dikarenakan kegiatan ini masih masa pandemic Covid19, maka metode yang digunakan dalam Pemberdayaan ini dilakukan secara luring menggunakan protokol kesehatan yang ketat.

\section{Pra-Kegiatan}

Pra-kegiatan diawali dengan observasi permasalahan, dimana dengan adanya masa pandemic covid-19 saat ini munculnya masalah terutama bidang ekonomi dan sosial. Tingginya harga produk kesehatan dan kecantikan termasuk kosmetik, serta daya beli masyarakat yang menurun karena krisis ekonomi yang belum pulih.

Berdasarkan informasi dari Kepala Desa Suram dan Ibu-ibu PKK, ditemui Kegiatan ibu-ibu PKK yang belum produktif sementara didaerah tersebut sumber daya alamnya sangat mendukung, seperti banyaknya masyarakat menanam aloevera disekitaran rumah mereka. Dari potensi tersebut, maka pemberdayaan Ibuibu PKK Desa Suka Ramai untuk mencari alternatif lain dalam menjaga kesehatan dan kecantikan dengan "kembali ke alam" (back to nature), sangat mungkin dilakukan.

Persiapan Kegiatan sudah dilakukan mulai awal Bulan Februari 2021, termasuk mengurus perizinan kegiatan ke Kantor Kepala Desa Suka Ramai dan akhirnya disepakati pelaksaan kegiatan Pemberdayaan dan pelatihan pembuatan facemist dilakukan secara luring pada tanggal 20 Maret 2021. Didalam persiapan Tim berdiskusi dengan Bapak Kepala Desa Suka Ramai, Bapak Arusman dan Ibu-ibu PKK tentang masalah yang dihadapi IbuIbu dan solusi yang ditawarkan sehingga dapat membantu memberi solusi terhadap masalah mereka, yaitu dengan membuat produk facemist multifungsi berbahan dasar aloevera dan ekstrak green tea. IbuIbu PKK sangat antusias, mereka nantinya sangat ingin bisa memproduksi setelah diajarkan tahap-tahap pembuatannya. Sebelum diadakannya pertemuan offline dengan Ibu-ibu PKK, Tim mencari kebutuhan alat, bahan serta membuat produk terlebih dahulu di Lab Kimia Universitas Muhammadiyah Riau.

\section{Pelaksanaan Kegiatan Pengabdian Kepada Masyarakat}

Ada dua kegiatan utama yang dilakukan pada kegiatan PKMS ini yaitu Sosialisasi dan pelatihan dengan metode Participant Learning Center yaitu: Pelatihan yang dikaitkan dengan 
pemecahan masalah kesehatan masyarakat dimasa Pandemik Covid-19, yang telah diidentifikasi sebelumnya (Problem Centered Orientation) agar bermanfaat dan praktis bagi ibu-ibu PKK dan remaja putri.

Kegiatan yang dilakukan yaitu: Sosialisasi kegiatan dan penyuluhan tentang khasiat tanaman yang digunakan sebagai bahan dasar facemist ke peserta, perencanaan, proses produksi, packaging, perancangan desain kemasan produk dan promosi dan pemasaran. Pendampingan juga dilakukan terhadap berbagai hal yang menjadi kendala. Disamping itu evaluasi terhadap tahapan-tahapan pelaksanaan kegiatan tersebut guna menyempurnakan tindakan berikutnya dalam upaya membantu masyarakat Desa Suka Ramai.

Kegiatan pelatihan dilakukan sesuai kebutuhan peserta dimana metode yang digunakan pada pemberdayaan ini dilakukan dengan cara: pertama metode ceramah dan tanya jawab, metode ini menyajikan teori secara umum. Seperti: pengembangan produk facemist multifungsi berbahan dasar aloevera dan ekstrak green tea yang akan menjadi salah satu oleh-oleh khas Desa Suka Ramai, pengenalan alat dan penggunaannya serta keselamatan kerja selama proses produksi. Penyajian materi pada metode ini menggunakan alat peraga berbentuk ceramah. Metode kedua adalah metode resitasi dan diskusi, dimana setelah tim pelaksana selesai menyajikan materi, tanya jawab dengan peserta dilakukan untuk melihat pemahaman para peserta tentang materi yang diberikan. Kegiatan pelatihan menggunakan pendekatan Participatory action (PA), dimana peserta pelatihan didampingi untuk mendaftarkan produk facemist ke Departemen Hukum dan HAM untuk mendapatkan Hak Cipta, mengembangkan pemasaran produk. Secara rinci metode pelaksanaan masingmasing kegiatan disajikan pada Tabel 1 berikut.

Tabel 1. Kegiatan, Tujuan, Metode, Bahan dan Alat Pendampingan

\begin{tabular}{|c|c|c|c|c|}
\hline No & Kegiatan & Tujuan Kegiatan & Metode & Bahan dan Alat \\
\hline 1 & Kontrak Kegiatan & $\begin{array}{l}\text { Membangun kesepahaman } \\
\text { mengenai tujuan dan } \\
\text { pelaksanaan PKM antara Tim } \\
\text { dan Mitra }\end{array}$ & $\begin{array}{l}\text { Ceramah, } \\
\text { diskusi, }\end{array}$ & $\begin{array}{l}\text { White board, } \\
\text { spidol, Kertas } \\
\text { Plano }\end{array}$ \\
\hline 2 & $\begin{array}{l}\text { Sosialisasi } \\
\text { Tanaman Obat }\end{array}$ & $\begin{array}{l}\text { Mitra mengetahui bahwa } \\
\text { tanaman yang selama ini ada } \\
\text { di lingkungannya bahkan } \\
\text { sering dianggap gulma bisa } \\
\text { dijadikan obat }\end{array}$ & $\begin{array}{l}\text { Ceramah, } \\
\text { diskusi, }\end{array}$ & $\begin{array}{l}\text { Infokus, laptop, } \\
\text { contoh tanaman }\end{array}$ \\
\hline 3 & $\begin{array}{l}\text { Pelatihan } \\
\text { pembuatan spray } \\
\text { multifungsi dari } \\
\text { aloevera dan } \\
\text { green tea }\end{array}$ & $\begin{array}{l}\text { Mitra mengerti pentingnya } \\
\text { membuat produk sesuai } \\
\text { dengan langkah-langkahnya } \\
\text { untuk menjadi produk } \\
\text { mempunyai nilai guna } \\
\text { maksimal }\end{array}$ & $\begin{array}{l}\text { Ceramah, } \\
\text { diskusi, }\end{array}$ & $\begin{array}{l}\text { Infokus, laptop, } \\
\text { sampel tanaman, } \\
\text { alat dan bahan } \\
\text { pembuatan } \\
\text { facemist }\end{array}$ \\
\hline 4 & $\begin{array}{l}\text { Pelatihan } \\
\text { standarisasi } \\
\text { produk dan } \\
\text { penggalian ide } \\
\text { produk lainnya }\end{array}$ & $\begin{array}{l}\text { Mitra mengerti pentingnya } \\
\text { standarisasi produk dan } \\
\text { melakukan peresepan standar } \\
\text { produk }\end{array}$ & $\begin{array}{l}\text { Ceramah, } \\
\text { diskusi, }\end{array}$ & $\begin{array}{l}\text { Materi standarisasi } \\
\text { produk }\end{array}$ \\
\hline
\end{tabular}




\begin{tabular}{|c|c|c|c|c|}
\hline 5 & $\begin{array}{l}\text { Pelatihan } \\
\text { Kemasan dan } \\
\text { Merk }\end{array}$ & $\begin{array}{l}\text { - Mitra memahami } \\
\text { pentingnya merk } \\
\text { - Mitra memahami } \\
\text { pentingnya kemasan yang } \\
\text { hygienis } \\
\text { - Mitra terampil mengemas } \\
\text { - Mitra mempunyai merk }\end{array}$ & $\begin{array}{c}\text { Ceramah, } \\
\text { Diskusi, } \\
\text { praktek }\end{array}$ & Packaging, Merk, \\
\hline 6 & $\begin{array}{l}\text { Menjelaskan cara } \\
\text { pendaftaran } \\
\text { Merek Dagang ke } \\
\text { Departemen } \\
\text { Hukum dan HAM }\end{array}$ & $\begin{array}{l}\text { Mitra mengetahui cara } \\
\text { mendaftarkan produk ke } \\
\text { Departemen Hukumdan } \\
\text { HAM sehingga dapat } \\
\text { menularkan pengalamannya } \\
\text { ke masyarakat lainnya }\end{array}$ & $\begin{array}{l}\text { Kunjungan } \\
\text { website }\end{array}$ & $\begin{array}{l}\text { Produk facemist } \\
\text { multiguna }\end{array}$ \\
\hline
\end{tabular}

\section{Evaluasi Kegiatan}

Evaluasi dilakukan dalam upaya memaksimalkan hasil kegiatan sesuai dengan target yang sudah ditentukan. Evaluasi dilakukan terhadap semua bentuk kegiatan yang dilakukan dalam semua tahap kegiatan. Apabila terdapat kegiatan yang memberikan hasil yang tidak maksimal maka dilakukan upaya penyempurnaan kegiatan tersebut.

Evaluasi dan Tindak lanjut Kegiatan dilakukan perbulan dari bulan April sampai September 2021. Evaluasi meliputi pra-kegiatan, pelaksanaan kegiatan maupun keberlanjutan dari program. Pra kegiatan perminggu dilakukan, dimana ketua dan anggota tim melaporkan progres sampai didapatkan tanggal yang tepat untuk dilakukannya pelatihan offline. Evaluasi kegiatan di akhir pelatihan berupa pesan, kesan dan masukan bagi Tim dari peserta pelatihan. Keberlanjutan program dipastikan dengan ikutnya Kepala Desa Suka Ramai mendukung dan memfasilitasi usaha tersebut.

\section{HASIL DAN PEMBAHASAN}

\section{Hasil yang Dicapai Pada Pelaksanaann Kegiatan Pengabdian Masyarakat}

Partisipasi mitra dalam pelaksanaan kegiatan ini sangat baik, terlihat pihak Mitra dalam hal ini adalah Bapak Kepala Desa Suka Ramai, menyatakan bersedia untuk mencarikan dan menyediakan tempat untuk sosialisasi, pelatihan, maupun menyediakan tempat untuk pendampingan produk. Semua kegiatan berjalan dengan lancar dengan protokol kesehatan Covid-19, dengan harapan masyarakat dalam hal ini Ibu-ibu anggota PKK, remaja putri dan anggota Posyandu Desa Suka Ramai bisa memanfaatkan kegiatan ini dengan baik dan memahami potensi tanaman dilingkungannya untuk dapat dibuat menajdi produk kesehatan dan kecantikan, bahkan dapat membantu perekonomian keluarga.

Minat peserta pelatihan yang terdiri dari anggota PKK, remaja putri, anggota Posyandu dan juga diikuti sebagian oleh Bapak-bapak Desa Suka Ramai. Kegiatan pelatihan Pembuatan Face Mist Multifungsi Dari Aloevera dan ekstrak Green Tea ini berjalan dengan lancar, hal ini terlihat dari antusisme peserta mengikuti acara dari pagi sampai sore hari masih penuh semangat. Pelatihan ini memberikan pengetahuan baru terhadap peserta dan Keterkaitannya dengan bisa nantinya dijadikan usaha rumahan yang akan bisa membantu perekonomian keluarganya. Kegiatan pengabdian kepada masyarakat ini di awali dengan tahap persiapan termasuk konsolidasi tim dan melakukan pertemuan di lokasi pengabdian dengan Kepala Desa Suka Ramai, Bapak Arusman, fiksasi jadwal dan tempat dengan pihak Mesjid Raya (Mesjid Jami') Desa Suka Ramai, Kec. Tapung Hulu, Kampar. 
Setelah mengadakan pertemuan dengan Kepala Desa tim pengabdian masyarakat yang terdiri dari tujuh orang dosen Prodi Kimia dan sembilan mahasiswa Prodi Kimia melakukan pembagian tugas pada masing-masing tim pengabdian masyakat. Tim pengabdian masyarakat melakukan persiapan alat dan bahan yang di perlukan untuk kegiatan pelatihan, diantaranya persiapan ruangan, perlengkapan pelatihan di antaranya materi seminar, media pelatihan LCD, infocus, makalah serta dokumentasi kegiatan. Sasaran dalam kegiatan pengabdian masyarakat ini adalah masyarakat Desa Suka Ramai, Kecamatan Tapung Hulu, Kab. Kampar.

Kegiatan pengabdian kepada masyarakat dilakukan dengan cara tatap muka secara langsung (luring) dengan peserta pelatihan yang berjumlah 50 orang. Secara keseluruhan kegiatan pelatihan berjalan dengan lancar dan tertib. Peserta antusias dalam mengikuti pelatihan yang terlihat pada saat kegiatan berlangsung di mana peserta pelatihan berperan aktif dalam sesi diskusi dan tanya jawab. Kegiatan pengabdian kepada masyarakat dilakukan dengan lima tahapan kegiatan. Kegiatan pengabdian masyarakat yang pertama

yaitu registrasi peserta, sambutan sekaligus membuka acara pada hari Sabtu, 20 Maret 2021 pada pukul 09.00 Wib s/d 17.00 wib. Peserta yang hadir pada kegiatan ini adalah Ibu-ibu anggota PKK,

Tabel 2. Jadwal Kegiatan Pengabdian Masyarakat di Desa Suka Ramai, Kec. Tapung Hulu, pada Hari Sabtu 20 Maret 2021

\begin{tabular}{cll}
\hline \multicolumn{1}{c}{ Waktu } & \multicolumn{1}{c}{ Aktivitas } & \multicolumn{1}{c}{ Penanggung jawab } \\
\hline $\mathbf{1 0 . 0 0}-\mathbf{1 1 . 0 0}$ & Reregistrasi peserta workshop & Kesekretariatan \\
\hline $\mathbf{1 1 . 0 0}-\mathbf{1 2 . 0 0}$ & Pembukaan Kegiatan Pengabdian & M.C \\
& Sambutan Ketua Panitia & Prasetya, M.Si \\
& Ssosialisasi Program Studi Kimia & Dr.Jufrizal Syahri, M.Si \\
& Sambutan Kepala Desa dan Kepala & Fitra Perdana,M.Si \\
& Kecataman sekaligus membuka acara & Arusman \\
\hline $\mathbf{1 3 . 0 0 - 1 3 . 3 0}$ & Sosialisasi Tanaman Obat & Rahmiwati Hilma, M.Si \\
\hline $\mathbf{1 3 . 3 0}-\mathbf{1 4 . 3 0}$ & Pelatihan pembuatan facemist & Rahmiwati Hilma, M.Si \\
& multifungsi dari aloevera dan green tea & \\
\hline
\end{tabular}

remaja putri, anggota Posyandu dan juga diikuti sebagian oleh Bapak-bapak di Desa Suka Ramai, sehingga jumlah total peserta adalah 50 orang.

Kegiatan pengabdian kepada masyarakat yang kedua yaitu Acara Pembukaan Kegiatan Pelatihan oleh Kepala Desa dan Bapak dari pihak Kecamatan Tapung Hulu. Selanjutnya kegiatan yang ketiga yaitu pelatihan pembuatan facemist yang disampaikan oleh narasumber dari Dosen Prodi Kimia, Universitas Muhammadiyah Riau yang ahli dibidangnya dan tentunya berkaitan dengan judul pengabdiannya. Pada hari yang sama pada pukul $13.00 \mathrm{Wib}$ s/d 16.00 wib. Pelatihan terdiri dari lima sesi, sesi pertama yaitu materi tentang Sosialisasi Tanaman Obat. Sesi ke-2 yaitu Pelatihan pembuatan spray multifungsi dari aloevera dan green tea, sesi ke-3 yaitu Pelatihan standarisasi produk dan penggalian ide produk lainnya. Sesi ke-4 yaitu Menjelaskan cara pendaftaran Hak Cipta ke Departemen Hukumdan HAM dan Sesi ke-5 yaitu praktik pembuatan face mist oleh peserta pelatihan. Output yang diharapkan setelah acara adalah, masingmasing peserta memiliki pemahaman tentang manfaat dari aloevera dan juga green tea, serta bisa memproduksi sendiri facemist, Secara terperinci terlihat pada Tabel 2 dan Tabel 3. 


\begin{tabular}{lll}
\hline \hline $\mathbf{1 4 . 3 0}-\mathbf{1 5 . 0 0}$ & $\begin{array}{l}\text { Pelatihan standarisasi produk dan } \\
\text { penggalian ide produk lainnya. }\end{array}$ & $\begin{array}{l}\text { Fitra Perdana,M.Si } \\
\text { Prasetya, M.Si }\end{array}$ \\
\hline $\mathbf{1 5 . 0 0 - \mathbf { 1 5 . 3 0 }}$ & $\begin{array}{l}\text { Menjelaskan cara pendaftaran Hak Cipta } \\
\text { ke Departemen Hukum dan HAM }\end{array}$ & Rahmadini Syafri, M.Sc \\
& Istirahat dan sholat ashar & Panitia \\
\hline $\mathbf{1 5 . 3 0 - \mathbf { 1 6 . 0 0 }}$ & $\begin{array}{l}\text { praktik pembuatan facemist oleh peserta } \\
\text { pelatihan }\end{array}$ & $\begin{array}{l}\text { Hasmalina Nasution, M.Si } \\
\text { Dr.Jufrizal Syahri, M.Si } \\
\text { Dr.Sri Hilma Siregar, M.Sc }\end{array}$ \\
\hline
\end{tabular}

Tabel 3. Jumlah Peserta Pengabdian Masyarakat di Desa Suram, Kec. Tapung Hulu

\begin{tabular}{ccc}
\hline Kategori Kegiatan & Jumlah & $\begin{array}{c}\text { Persentase } \\
\text { kehadiran }\end{array}$ \\
\hline Kegiatan 1 & 50 & $100 \%$ \\
\hline Kegiatan 2 & 50 & $100 \%$ \\
\hline Kegiatan 3 & 50 & $100 \%$ \\
\hline Kegiatan 4 & 50 & $100 \%$ \\
\hline Kegiatan 5 & 50 & $100 \%$ \\
\hline Kegiatan 6 & 50 & $100 \%$ \\
\hline
\end{tabular}

Berdasarkan data pada Table 3 terlihat bahwa $100 \%$ peserta workshop hadir di setiap kegiatan. Hal ini membuktikan antusiasme dan minat masyarakat Desa Suak Ramai, Kec. Tapung Hulu, Kab, Kampar dalam mengikuti pelatihan pembuatan facemist ini sangat tinggi. Workshop ini telah berhasil dan sukses dilaksanakan di Mesjid Raya (Mesjid Jami') Desa Suka Ramai, terbukti dengan antusiasme para peserta pelatihan berhasil dalam mempraktikkan pembuatan facemist.

Seluruh peserta antusias dengan kegiatan dan penjelasan yang di berikan oleh narasumber. Adapun Narasumber dalam kegiatan ini adalah 4 orang dengan rincian materi yangdisampaikan adalah:

Pembicara 1, Menyampaikan materi yang berkaitan dengan Sosialisasi Tanaman Obat dan Pelatihan pembuatan facemist multifungsi dari aloevera dan green tea.

Pembicara 2, Menyampaikan materi yang berkaitan dengan Pelatihan standarisasi produk dan penggalian ide produk lainnya

Pembicara 3, Menyampaikan materi yang berkaitan dengan Menjelaskan cara pendaftaran Hak Cipta ke Departemen Hukum dan HAM

Pembicara 4, Menyampaikan materi yang berkaitan dengan Teknik pembuatan face mist campuran aloevera dan ekstrak green tea

Pada saat kegiatan berlangsung terlihat bahwa para peserta pelatihan yang terdiri dari Ibu-ibu PKK dan remaja putri umumnya dapat memahami dengan baik pembuatan facemist dan bagaimana menjadikan bahan yang ada disekiling kita dapat dijadikan produk yang mempunyai nilai jual. Dengan adanya kegiatan pelatihan ini maka diharapkan dapat meningkatkan pengetahuan, pemahaman dan kemampuan masyarakat Desa Suka Ramai dalam membuat facemist serta mampu menjadikannya produk yang bisa menjadi produk unggulan Desa sehingga tercapai tujuan dari Pemberdayaan Ibu-ibu PKK dan remaja putri melalui pelatihan pembuatan facemist multifungsi, di Desa Suka Ramai, Kec. Tapung Hulu, Kabupaten Kampar

Hasil kegiatan Pengabdian masyarakat secara garis besar mencakup beberapa komponen sebagai berikut:

1. Keberhasilan target jumlah peserta pelatihan. 
Kegiatan pemberdayaan berupa pelatihan terhadap Ibu-ibu PKK, Kader Posyandu dan remaja putri, telah berhasil dilakukan, dimana tim berhasil merangkul peserta untuk ikut serta berpartisipasi dalam acara ini terbukti dengan kehadiran peserta baik disesi pertama dan juga disesi kedua dan kehadirannya melebihi $50 \%$.

2. Tercapainya tujuan pelatihan

Pada dasarnya tujuan dari penyuluhan ini adalah meningkatnya pengetahuan, pemahaman dan kemampuan masyarakat terhadap materi pelatihan, yang nantinya dapat digunakan bagi mereka untuk mencoba memulai membuat produk untuk penggunaan pribadi atau untuk membuka usaha baru. Ibu-ibu PKK dan remaja putri yang mendapatkan pelatihan diharapkan juga dapat menyebarkan informasi dan membimbing masyarakat lainnya dalam membuat facemist. Melalui cara ini penyebaran informasi dapat berjalan lebih cepat.

Pada saat pelaksanaan kegiatan terlihat antusiasme peserta dengan berbagai pertanyaan yang dilontarkan oleh peserta. Pada saat praktek pembuatan facemist, peserta diberikan waktu untuk mencoba memproduksi sendiri, sehingga diharapkan peserta bisa lebih mahir dalam membuat dan mengajarkan lagi ke masyarakat lainnya.

\section{Evaluasi Kegiatan Pengabdian Kepada Masyarakat}

Evaluasi menyeluruh dilakukan setelah serangkaian kegiatan dilakukan untuk perbaikan. Ibu-ibu PKK masih menghubungi tim melalui video call maupun whatsapp. Bapak Arusman sangat berterima kasih atas kegiatan kami yang dilaksanakan dan dia berharap akan ada kegiatan lain dari UM-Riau, PT. Chevron Pacific Indonesia (sekarang sudah berubah menjadi PT. Pertamina Hulu Rokan) ataupun Kemedikbud yang akan bekerjasama lagi dengan ibu-ibu PKK atau dengan Desa Suka Ramai untuk membangun Desa lebih maju lagi. Bagi tim kegiatan evaluasi dilakukan setiap akhir minggu untuk berdiskusi dan memberi masukan untuk tahap-tahap yang sudah dilakukan maupun yang belum dilakukan. Adanya koordiansi yang lebih intens antara sesama anggota tim maupun dengan Bapak Kepala Desa sangat membantu kegiatan ini berjalan lancar.

\section{Keberlanjutan Progam}

Keberlanjutan Program Kegiatan Pengabdian Masyarakat Stimulus untuk menjadikan produk facemist multifungsi berbahan dasar Aloevera dan ekstrak Green Tea sebagai oleh-oleh dari Desa Teluk Suka Ramai sangat didukung oleh pemerintahan Desa Teluk Kenidai. Pak Arusman, begitu antusias dan juga mengajak ibu-ibu PKK untuk mensuport kegiatan ini. Pak Arusman juga akan berusaha untuk terus memantau kegiatan ini sehingga benar-benar berkelanjutan dan menjadi solusi untuk peningkatan ekonomi kreatif di Desa Suka Ramai.

\section{Manfaat Dari Terlaksananya Kegiatan}

Berikut merupakan potensi yang dimiliki dari hasil yang telah dicapai pada pelaksanaan kegiatan pengabdian kepada masyarakat berupa Pemberdayaan Ibu-Ibu PKK, Kader Posyandu dan remaja Putri ini terbentuknya kelompok usaha baru, dengan mengangkat produk facemist berbahan dasar aloevera dann ekstrak green Tea sehingga bisa menjadi produk unggulan Desa Suka Ramai.

Setelah dilakukannya kegiatan pemberdayaan ini masyarat sangat antusias untuk bisa memproduksi produk yang kami tawarkan. Hal ini tentu akan memberikan omset tambahan bagi ibu-ibu PKK. Kelompok usaha ini nantinya akan bisa berkembang menjadi kelompok usaha yang lebih produktif dan berkesinambungan dengan adanya 
dukungan dari Kepala Desa Suka Ramai. Hal ini tentu saja akan menjadi salah satu usaha untuk ikut mengentaskan kemiskinan yang ada di Desa Suka Ramai.

Bagi Dosen kegiatan ini menjadi sebagai ajang untuk bisa terjun ke masyarakat langsung membagikan ilmu yang selama ini digeluti. Dosen bisa berbagi ilmu kewirausahaan seperti: produksi, manajemen usaha, pembuatan packaging dan ilmu marketingnya. Tentu saja disini sangat diperlukan tim work yang baik.

\section{Sosial, Ekonomi dan Pendidikan}

Keberlanjutan program adalah target lain yang harus dicapai, agar ketika pelaksanaan kegiatan ini selesai warga sekitar memilki kemampuan untuk melanjutkan program, memproduksi dengan mandiri serta terbentuknya jiwa kewirausahaan masyarakat. Dari segi ekonomi, Kelompok Ibu-ibu PKK Desa Suka Ramai akan mendapatkan income dari hasil menjualan produk facemist ini. Dengan adanya bekal materi manajemen usaha akan menjadikan kelompok usaha ini bisa mandiri dan akan lebih maju kedepannya. Pada Kegiatan ini terjadi transfer ilmu pengetahuan dari perguruan tinggi kepada masyarakat sehingga masyarakat mampu memahami cara pemanfaaatan sumber daya alam yang ada di sekitar yang dapat menyelesaikan permasalahan yang ada di masyarakat.

\section{Peluang perolehan Hak Cipta Berupa Pendaftran Brand}

Perbedaan dengan produk yang sudah ada terletak pada kreativitas pembuatannya dan brand facemist "ESM". Brand atau merek dagang berpeluang untuk didaftarkan ke PJTI Kementrian Hukum dan Ham serta Dinas Perindustrian dan Perdagangan Propinsi Riau.

\section{Potensi Pengembangan Usaha}

Dengan kondisi cuaca yang sangat panas di Propinsi Riau saat ini, produk facemist ini banyak diminati oleh masyarakat. Kelompok Usaha ibu PKK Desa Suka Ramai dengan produk facemist berbahan dasar aloevera dan ekstrak green Tea memiliki potensi untuk dikembangkan. Produk facemist ini akan menjadi produk khas Desa Suka Ramai, dan akan dipilih karena lebih praktis, alami dan memiliki khasiat untuk Kesehatan dan kecantikan. Kedepannya produk ini diharapkan mendapatkan izin produksi, label halal, dan pendaftaran brand, sehingga menjadi produk andalan di Desa Suka Ramai.

\section{SIMPULAN}

Kegiatan Pemberdayaan Ibu-ibu PKK, Kader Posyandu dan remaja putri melalui pelatihan pembuatan facemist multi fungsi dari aloevera dan ekstrak green tea di Desa Suka Ramai, Kec. Tapung Hulu, Kab. Kampar mendapat sambutan yang baik dari peserta dan berhasil dengan baik. Kehadiran peserta yang hampir mencapai $100 \%$ dari awal sampai akhir kegiatan. Pembuatan produk facemist berhasil dilakukan oleh peserta, sehingga target dari kegiatan tercapai.

\section{UCAPAN TERIMAKASIH}

Ucapan terima kasih disampaikan kepada PT. Chevron Pacific Indonesia (CPI) melalui Program University Relationship Program (URP) Tahun 20202021 yang telah membantu dalam pendanaan sehingga kegiatan pengabdian ini dapat berjalan dengan baik

\section{DAFTAR PUSTAKA}

[1] Badan Pusat Statistik Kabupaten Kampar, 2021. Statistik Kabupaten Kampar Tahun 2021.

[2] Ismail, R. I. and Siste, K., 2010, Gangguan Depresi, Buku Ajar Psikiatri, Fakultas Kedokteran Universitas Indonesia, Jakarta

[3] Furnawanthi, I. 2002. Khasiat \& Manfaat Lidah Buaya Si Tanaman 
Ajaib. Agro media pustaka. Jakarta.

Hal 1-21.

[4] Dalimartha, Setiawan. (2000). Atlas

Tumbuhan Obat Indonesia. Jilid 2, Trubus Agriwidya, Jakarta.

[5] Chatterjee, A., T. Das, A. Basu, K. Adak, S. Banerjee, and S. Ghosh. (2016). Adverse effects of tea metabolites extracted during Indian household tea preparations on digestive enzymes and iron. International Journal of Advanced Research 4(9): 1179-1189.

[6] Maeda-Yamamoto M, Ema K, Shibuichi I. In vitro and in vivo antiallergic effects of 'benifuuki' green tea containing 0 -methylated catechin and ginger extract nhancement. Cytotechnology. 2007;55:135-42.

[7] Hilma, R., Gustina, N., Syahri, J., 2019. Pengukuran Total Fenolik, Flavonoid, Aktivitas Antioksidan dan Antidiabetes Ekstrak Etil Asetat Daun Katemas (Euphorbia heterophylla, L.) Secara In Vitro dan In Silico Melalui Inhibisi Enzim $\alpha$ Glukosidase. ALCHEMY Jurnal Penelitian Kimia, Vol. 16(2): 240249

[1]. [8] Puspita, W., Puspasari, H., Restanti, N.A.,2020, Formulasi Dan Pengujian Sifat Fisik Sediaan Spray Gel Ekstrak Etanol Daun Buas-Buas (Premna serratifolia L.), Jurnal IImiah Farmako Bahari, 11 (2) 